\title{
The optimal method with which to assess right ventricular function
}

\author{
M. Vogel \\ Department of Congenital Heart Disease, German Heart Center, Berlin, Germany
}

\section{$\mathrm{T}$} HERE IS GENERAL AGREEMENT THAT EVALUATION of right ventricular function is important ${ }^{1}$ in the pre-immediate postoperative, and longterm assessment of many patients with congenitally malformed hearts, such as those with atrial septal defect, anomalous pulmonary venous connection, tetralogy of Fallot, and lesions where the right ventricle supports the systemic circulation. $2,3,4$ Routine evaluation is difficult, as simple geometric formulas cannot reliably be used to determine ventricular volume. ${ }^{5}$ Recently, three-dimensional echocardiography has become available, ${ }^{6}$ and has been successfully applied for the assessment of left ventricular volumes, ${ }^{7}$ and for experimental measurement of right ventricular volumes. ${ }^{8,9}$ Further clinical use, or routine application, of three-dimensional echocardiography, however, has been hindered by the expensive hardware, which is not universally portable, ${ }^{6}$ by lack of dedicated probes designed for real-time three-dimensional echocardiography in children, ${ }^{10}$ by the time requirements for reconstruction of the volumes, and last but not least, by the additional cost. The current paper by Heusch et al. ${ }^{11}$ points to other important problems. The method of three-dimensional reconstruction using a conventional cross-sectional echocardiographic probe and a probe holder with external rotational capabilities which uses analog data from the videosignal of the echocardiographic machine, may in the first place not be applicable in all patients, and second may not be as accurate as desired. The latter problem may reflect the fact, that first, rotational scanning may not be the

Correspondence to: Prof Michael Vogel, Department of Congenital Heart Disease/Paediatric Cardiology, German Heart Center, Postfach 650505, 13305 Berlin, Germany. Tel: +49 304593 2822; Fax: +49 304593 2826; E-mail mvogel@dhzb.de

Accepted for publication 18 June 1999 optimal method with which to aquire transthoracic echocardiographic data suitable for reconstruction, ${ }^{12}$ second, that a possibly not so golden standard, angiography as opposed to magnetic resonance imaging, was used for comparison. ${ }^{13} \mathrm{~A}$ third potential flaw was that the manual outline drawn during echocardiographic measurements of the internal ventricular contour excluded major trabeculations and papillary muscles. A possible explanation for the poor agreement between angiography and three-dimensional echocardiography may be that, in the angiographic measurements, trabeculations and papillary muscles cannot be as well seen as with echocardiography, and may not have been completely excluded from the right ventricular cavity. This may well explain why, in the study of Heusch et al., ${ }^{11}$ echocardiographic measurements uniformly yielded smaller right ventricular volumes than did angiographic data. Comparison with published echocardiographic studies demonstrates that their is no unaminous agreement whether the trabeculations and papillary muscles should or should not be included in the designated cavity. ${ }^{14,15,16}$ An important step to improve non-invasive assessment of right ventricular volumes may be an official recommendation by the respective working groups on echocardiography on both sides of the Atlantic as to how to consider trabeculations and papillary muscles during volumetry. In the past 2 years, new technical developments, such as improved spatial resolution of real-time volumetric three-dimensional echocardiography, the use of digital rather then analog data for reconstruction, and dedicated integrated probes for transthoracic scanning, ${ }^{7}$ have not only improved the clinical applicability of threedimensional echocardiography, but also offered the option of providing more accurate data on right ventricular function. This should be assessed in the future by comparing the newer techniques of three- 
dimensional echocardiography with the accepted golden standard of magnetic resonance imaging. The latter technique, like three-dimensional echocardiography, can image right ventricular trabeculations and papillary muscles. It, too, permits the measurement of volumes irrespective of the complex shape of the ventricle. ${ }^{17}$

\section{References}

1. Oldershaw P. Assessment of right ventricular function and its role in clinical practice. Br Heart J 1992;68: 12-15

2. Berger $F$, Jin Z, Ishihashi $K$, Vogel $M$, Ewert P, AlexiMeskishvili V, Weng Y, Lange PE. Comparison of acute effects of surgical versus interventional closure of atrial septal defects on right ventricular haemodynamics. Cardiol Young 1999; 9(5): $484-487$

3. Fuster V, McGoon DC, Kennedy MA. Long-term evaluation of open heart surgery for tetralogy of Fallot. Am J Cardiol 1984;54: 945-951

4. Redington AN, Rigby ML, Oldershaw PJ, Gibson DG, Shinebourne EA. Right ventricular function 10 years after the Mustard operation for transposition of the great arteries: analysis of size,shape, and wall motion. Br Heart J 1989;62: $455-461$

5. Helbing WA, Rebergen SA, Maliepaard C, Hansen B, Ottenkamp J, Reiber JHC, de Roos A. Quantification of right ventricular function with magnetic resonance imaging in children with normal hearts and with congenital heart disease. Am Heart J 1995;130: 828-837

6. Vogel M, Ho SY, Bühlmeyer K, Anderson RH. Assessment of congenital heart defects by dynamic three-dimensional echocardiography: Methods of data acquisition and clinical utility. Acta Paediat 1995; Suppl 410: 34-39

7. Acar P, Maunoury C, Antonietri T, Bonnet D, Sidi D, Kachaner $\mathrm{J}$. Left ventricular ejection fraction in children measured by three-dimensional echocardiogaphy using a new transthoracic integrated 3D-probe. A comparison with equilibrium radionuclide angiogaphy. Eur Heart J 1998; 19: 183-1588

8. Linker DT, Moritz WE, Pearlman AS. A new three-dimensional echocardiographic method of right ventricular volume measurement: in vitro validation. J Am Coll Cardiol 1986;8: 101-106

9. Vogel $\mathrm{M}$, White $\mathrm{PA}$; Redington $\mathrm{AN}$. In vitro validation or right ventricular volume measurement by three-dimensional echocardiography. Br Heart J 1995; 74: 460-463

10. Shiota T, Jones M, Chikada M, Fleishman CE, Castellucci JB, Cotter B, deMaria AN, von Ramm OT, Kisslo J, Ryan T, Sahn DJ. Real-time three-dimensional echocardiography for determining right ventricular stroke volume in an animal model of chronic right ventricular volume overload. Circulation 1998;97: $1897-1900$

11. Heusch A, Rübo J, Krogmann ON, Bourgeois M. Volumetric analysis of right ventricular volume in children with congenital heart disease using three-dimensional echocardiography. Cardiol Young 1999; 9 (6): 577-584

12. Delabays A, Pandian NG, Cao QL, Sugeng L, Marx G, Ludomirsky A, Schwartz SL. Transthoracic real-time threedimensional echocardiogaphy using a fan-like scanning approach for data acquisition: methods, strenghts, problems and initial clinical experience. Echocardiography 1995;12: 49-59

13. Higgins CB. Which standard has the gold? J Am Coll Cardiol 1992; 19: 1608-1609

14. Jiang L, Siu SC, Handschumacher MD,Guerrerro JL, Prada JAV, King ME, Weyman AE, Levine RA. Three-dimensional echocardiography: in vivo validation for right ventricular volume and function. Circulation 1994;89: 2342-2350

15. Apfel HD, Solowiejczyk DE, Printz BF, Challenger M, Blood DKm Boxt LM, Barst RJ, Gersony WM. Feasibility of a twodimensional echocardiographic method for the clinical assessment of right ventricular volume and function in children. J Am Soc Echocardiogr 1996;9: 637645

16. Vogel $M$, Gutberlet $M$, Dittrich $S$, Hosten $N$, Lange PE. Comparison of transthoracic three-dimensional echocardiography with magnetic resonance imaging in the assessment of right ventricular volume and mass. Heart 1997; 78: 127-130

17. Helbing WA, Bosch HG, Maliepaard C, Rebergen SA, van der Geest RJ, Hansen B, Ottenkamp J, Reiber JHC, de Roos A. Comparison of echocardiographic methods with magnetic resonance imaging for assessment of right ventricular function in children. Am J Cardiol 1995; 76: 589-594 